\title{
CYTOTOXIC ACTIVITIES PROFILE OF PARASITE MANGO (Dendrophthoe pentandra) FROM VARIOUS AREAS IN INDONESIA AGAINST T47D BREAST CANCER CELLS AND NORMAL VERO CELL LINES
}

\author{
Roihatul Mutiah*1 \\ ${ }^{I}$ Departement of Pharmacy, Faculty of Medical and Health Sciences, Universitas Islam Negeri Maulana Malik \\ Ibrahim, Malang, Indonesia \\ *email: roiha@farmasi.uin-malang.ac.id
}

\begin{abstract}
Indonesia has so many kinds of a parasite (mistletoe), one of them which has potential anticancer activity is mango parasite (Dendrophthoe pentandra). This research aimed at determining the cytotoxic activity profile of mango parasite leaves extracts from several locations in Indonesia against T47D and Vero cell lines. Mango parasite leaves obtained from 4 locations in Indonesia: Kediri, Pekalongan, Sumatra, and Kalimantan. Three samples was obtained from 3 different sub-districts in each locations. Cytotoxic activities of samples were performed by MTT assay method. The results of this study showed that there were differences between samples obtained from different locations, especially in cytotoxic activity and selectivity indexes of mango parasite leaves (D. pentandra) ethanol extract. D. pentandra obtained from Kalimantan has the most potential cytotoxic activity and could be potentially developed into a T47D breast anticancer agent. Extracts from the Kalimantan have an $I_{50}$ values of $287.39 \mu \mathrm{g} /$ $\mathrm{ml}, L C_{50} 798.28 \mu \mathrm{g} / \mathrm{ml}$ and selectivity index 2.77, which means it was toxic to cancer cells but safe for Vero cell lines, and its selectively kills cancer cells rather than Vero cell lines. The result of this study could support D. pentandra to be developed as a new potential Fitofarmaka.
\end{abstract}

\section{INTRODUCTION}

Cancer is one of the main causes of death with an increasing number of sufferers every year. The Union for International Cancer Control (UICC) estimates that cancer cases annually reach one hundred new cases from one hundred thousand people in the world, including Indonesia [1]. One type of cancer that causes the most deaths in the world is breast cancer (Maharani, 2009). Based on cancer data in Indonesia in 2010 it is estimated that the incidence in Indonesia is 12 / 100,000 women, whereas in America there are around 92 / 100,000 women with high mortality of 27 / 100,000 or $18 \%$ of deaths found in women [2].

The treatment methods that widely used today are chemotherapy, radiation, and surgery methods. These methods have not been maximal, even giving side effects to normal cells that are around cancer cells or other organs. Surgery will be successful in some tumors that have developed, but it is difficult to treat in the early stages of metastasis. Treatment with radiation J. Islamic Pharm., an open access journal

ISSN: 2527-6123 
can kill local tumors, but radiation will also kill the surrounding healthy cells. While chemotherapy can also cause cancer cell resistance, so the anticancer compounds are not sensitive [3].

Efforts to find new treatments that are safe and selective for cancer growth need to be done. The new drug might obtained from plant compounds. Anticancer compounds from plants and until now still used in medicine, namely vinca alkaloids (Catharanthus), epipodophyllotoxins, taxanes, flavonoids and camptothecins [4].

One of the plants that can be used by the community as an anticancer drug is the mango parasite (Dendrophthoe pentandra). Not only as an anticancer agent, but it turns out that Dendrophthoe pentandra (D. pentandra) has many benefits, including cough medicine, diabetes, hypertension, diuretics, smallpox, ulcers, skin infections and postpartum treatment (Artanti et al., 2012). The compounds contained in the parasite extract are flavonoids, amino acids, carbohydrates, tannins, alkaloids and saponins [5]. The main flavonoids found in parasites and function as anticancer are quercetin compounds. Quercetin is a flavonoid derivative compound that has antioxidant, anti-inflammatory and anticancer activity, and is a cytochrome P450 3A4 inhibitor and modulator of ABCB1 [6].

Potential D.pentandra's as an anticancer agent needs to be supported by conducting further research. This study used leaves D.pentandra taken from various regions in Indonesia, namely Central Lampung (Sumatra), Bulungan (Kalimantan), Kediri (East Java) and Pekalongan (Central Java). The selection of the four locations based on differences in elevation of the place where grew D. pentandra. Lampung Tengah has a height of $27 \mathrm{~m}$ above sea level, Bulungan has an elevation of $80 \mathrm{~m}$ above sea level, Kediri has an elevation of $222 \mathrm{~m}$ above sea level, Pekalongan has a height of $8 \mathrm{~m}$ above sea level. This study aimed to determine the cytotoxic activity of $96 \%$ ethanol extract of leaves D. pentandra from various regions in Indonesia towards T47D breast cancer cells and Vero cells. The selectivity of extract $D$. pentandra can be seen from the scientific data in this study. The results obtained can be the basis for the use of leaves D. pentandra as a selective and safe anticancer agent. 


\section{MATERIAL AND METHOD}

\section{Materials of Plant}

The plant material used was leaf $D$. pentandra extracted using an ultrasonic method using ethanol $96 \%$ solvent for 20 minutes with a material ratio: solution 1:10 (b / v) [7]. Plant determination is carried out at LIPI Purwodadi, Pasuruan.

\section{Cancer Cell Lines}

Human cancer cells used are T47D breast cancer cells and normal Vero epithelial cells which are collections of the Faculty of Medicine, Gadjah Mada University (UGM) Yogyakarta.

\section{Chemicals}

Ethanol 96\%, M199 culture media and media Rose well Park Memorial Institute (RPMI), Dimethyl Sulfoxide (DMSO), tetrazolium salt micro-culture (MTT) $5 \mathrm{mg} / \mathrm{mL}$, Phosphate Buffer Saline (PBS) (50 mg MTT and 10 mL PBS), Sodium Dodecyl Sulfate 10\% (SDS) in $0.1 \mathrm{~N} \mathrm{HCl.}$

\section{Cytotoxicity Assay using MTT Method}

T47D cancer cells and Vero cells are placed in a 96 well plate, each of which contains $10^{4}$ cells. Cell calculations needed by multiplying $10^{4}$ cells required for each seed with 100 (the result of the fulfillment of the number of seedlings) divided by the calculated cells. After being distributed evenly, the cells incubated until the condition returns to normal. Added variations in the concentration of the test solution and incubated for 24 hours in a 5\% COincubator 2 . Each seed added $100 \mu \mathrm{L}$ of MTT solution and pre-incubated for 4 hours, formazan crystals will form as a result of enzymatic reactions that occur between living cells and MTT solutions. The MTT reaction stopped with a stopper reagent $(10 \% \mathrm{HCl}$ in SDS), then incubated overnight at room temperature. The next day an absorbance reading was carried out with ELISA reader at a wavelength of $595 \mathrm{~nm}$ [8].

\section{RESULT AND DISCUSSION}

\section{Cytotoxic activity of Parasite Mango (Dendrophthoe pentandra)}

This study aims to determine whether there are differences in cytotoxic activity against T47D cells and Vero cells from parasite mango (D. pentadra) in various locations grown in Indonesia. The cytotoxicity test was carried out on ethanol extract of mango parasite leaves 
(D.pentandra) from several locations in Indonesia, namely Kediri, Pekalongan, Sumatra and Kalimantan. The cells used were T47D breast cancer cells and Vero cells. The results showed that the ethanol extract of mango parasite leaves (D.pentandra) from the 4 locations could inhibit the growth of T47D cancer cells and Vero normal cells with a dose-dependent phenomenon, which was indicated by toxic effects increasing with increasing concentration. The graph of the profile of cell viability is presented in Figure 1 for T47D breast cancer and figure 2 for Vero cells. The results of analysis with linear regression obtained ICvalues shown $_{5}$ in table 1.

The results of the cytotoxicity assay showed that the ethanol extract of mistletoe leaves mango (D. pentandra) from the location of Kediri and Kalimantan potential as anticancer agents T47D breast (Table 1) because, in the previous report the extract is said to be active as an anticancer agent if the value of the $\mathrm{IC}_{50}<500 \mu \mathrm{g} / \mathrm{ml}$ [9]. These results are in line with the results of the toxicity tests that have been carried out, namely all extracts are not toxic tovero cells except extract from the Kediri location, with values $\mathrm{LC}_{50} 26.61 \mu \mathrm{g} / \mathrm{ml}$. The substance is said to have high cytotoxicity against Vero cells and is harmful to the body if it has IC50<100 $\mu \mathrm{g} / \mathrm{ml}[10]$. The results of the toxicity test can be seen in table 1 .

In previous studies, the mangoes parasite ( $D$. pentadra) has been reported to have potential as an anticancer. Anticancer Activity of Combination of mangoes parasite and Sabrang Onion (Eleutherine palmifolia (L) Merr) on Cervical Cancer Hela Cell Line [11]. The research conducted by Helda et al., the results of cytotoxicity test fractions of mango parasite leaves $(D$. pentandra) on cell line T47D breast cancer which showed the most active portion was the chloroform fraction with $\mathrm{IC}_{50}$ value $88,533 \mu \mathrm{g} / \mathrm{ml}$ [12]. From these studies can be the basis of reference that mango parasite leaves (D. pentandra) has the potential as an anticancer agent and also has the potential to be developed into phytopharmaca products.

The development of raw materials for medicinal plants to become phytopharmaca products has experienced problems which one of them caused by the varied content of multicomponent compounds in plants. Factors that cause this variation can divided into two, namely internal and external factors [13]. One of the external factors that significantly affect the content of secondary metabolites from plants is the difference in location of growth. The difference in plant growth location will make a difference in the composition or amount of the 
metabolite content of compounds that play a role in certain biological activities which will ultimately make a difference in the potential of their actions.

The anticancer activity test of ethanol extract of mango parasite leaves from 4 locations was carried out in vitro using culture on the cell line T47D using the MTT method. The MTT test is a sensitive, quantitative and reliable test. The MTT reaction is a cellular reduction reaction based on the breakdown of yellow MTT tetrazolium salts into purplish blue formazan crystals [14]. The color change method is used to detect cell proliferation. Cells that have proliferation, mitochondria absorb MTT so that the cells will be purple due to the formation of tetrazolium crystals (formazan) [15].

The price of $\mathrm{IC}_{50}$ obtained reflects the cytotoxicity of the material to the test cell. Based on the criteria set by the NCI (National Cancer Institute) [16], that an extract is declared active has anticancer activity if it has an $\mathrm{IC}_{50}$ value of $<30 \mu \mathrm{g} / \mathrm{ml}$, moderate active if it has an $\mathrm{IC}_{50}$ value of $\geq 30 \mu \mathrm{g} / \mathrm{ml}$ and $\mathrm{IC}_{50}<100 \mu \mathrm{g} / \mathrm{ml}$, and is said to be inactive if the $\mathrm{IC}_{50}$ value is $>100 \mu \mathrm{g}$ $/ \mathrm{ml}$. However, it does not mean that extracts from parts of plants that have $\mathrm{IC}_{50}>100 \mu \mathrm{g} / \mathrm{ml}$ are not potentially developed as anticancer because, extracts are said to be inactive as anticancer if the $\mathrm{IC}_{50}$ value is $>500 \mu \mathrm{g} / \mathrm{ml}$ [9]. It can conclude that from 4 to extract tested anticancer activity with MTT method most likely is an extract from the location of Kalimantan with an $\mathrm{IC}_{50}$ average $287.39 \mathrm{ug} / \mathrm{ml}$ and Kediri with $\mathrm{IC}_{50}$ values $304.79 \mu \mathrm{g} / \mathrm{ml}$.

The $\mathrm{LC}_{50}$ value obtained illustrates the toxicity of extracts against cell line. The substance is said to have high cytotoxicity to Vero cells and is harmful to the body if it has IC50<100 $\mu \mathrm{g} / \mathrm{mL}$. The results showed that only extracts from Kediri had a toxic effect on normal cells with values $\mathrm{LC}_{50} 26.61 \mu \mathrm{g} / \mathrm{ml}$, extracts from Kalimantan, Sumatra and Pekalongan locations were not toxic to vero cells with values $\mathrm{LC}_{50}$ respectively $798.28 \mu \mathrm{g} / \mathrm{ml}, 4845.32 \mu \mathrm{g} / \mathrm{ml}, 1583.75 \mu \mathrm{g} / \mathrm{ml}$.

\section{Determination of selectivity}

Selective means that only cells identified as cancer cells attacked, while normal cells not attacked. The selectivity index is the ability of a compound to select cancer cells compared to Vero cells selectively. This mechanism is very different from the way chemotherapy drugs work that attack cancer cells and also healthy cells. As a result, normal cells are damaged and die, which results in various side effects. 
Selectivity of each ethanol extracts of mango parasite leaves (D. pentandra), obtained from Kediri, Pekalongan, Sumatra, and Kalimantan, against T47D breast cancer cells were evaluated based on their Selectivity index (SI) parameter. The extract has high selectivity if the SI value was $\geq 3$, and has less selectivity if the SI value was <3. The results of selectivity analysis showed that the ethanol extract of mango parasite leaves (D.pentandra) from Sumatra was particularly selective against T47D breast cancer cell lines (SI values more than 3) (Table 2).

The results of the cytotoxicity and toxicity test can see that from the four extracts that have the most potential to be anticancer agents are extracts from the Kalimantan location with values $\mathrm{IC}_{50} 287.39 \mu \mathrm{g} / \mathrm{ml}$ and $\mathrm{LC}_{50} 798.28 \mu \mathrm{g} / \mathrm{ml}$. Extracts from the Kalimantan site have a toxic effect on T47D breast cancer cells and are also safe for Vero cells. The selectivity index (SI) of the four extracts showed that only extracts from Sumatra which had a selectivity index exceeding 3 , namely 8.96. The extract from Kalimantan has a selectivity index of 2.77 , where the value is almost close to 3. Extracts from the locations of Sumatra and Kalimantan are more selective in killing cancer cells than Vero cells which are analogous to normal body cells.

\section{CONCLUSION}

There were differences in cytotoxic activity and selectivity of indexes from the ethanol extract of mango parasite leaves (D. pentandra) from the locations of Kediri, Pekalongan, Sumatra, and Kalimantan. Kalimantan has the most potential to be developed into a T47D breast anticancer agent. Extracts from the Kalimantan location have values $\mathrm{IC}_{50} 287.39 \mu \mathrm{g} / \mathrm{ml}, \mathrm{LC}_{50} 798.28 \mu \mathrm{g} / \mathrm{ml}$ and selectivity index 2.77, which means toxic to cancer cells but is safe for Vero cells, and selectively kills cancer cells than Vero cells.

\section{REFERENCES}

[1] UICC.2012.http://www.cing.ac.cy/images/media/file/UICC\%20Cancer\%20declaration.p df accessed on November 20, 2012.

[2] RI Ministry of Health. 2014. Guide to management of breast cancer. Jakarta Balai Pustaka

[3] Lockshinm RA, Zakeri Z. 2007. Cell Death in Health and Disease, J. Cell.Mol.Med., 11 (6), 1214-1224.

[4] Balunas, MJ and Kinghorn, AD. 2005. Drug Discovery from Medicinal Plants. Journal of Life Sciences. 78 (5): 431-441. 
[5] Katrin, Soemardji AA, Soeganda AG, Soediro I. 2005. Acute Toxicity of Isolates of nHexana Fraction and Ethanol Dendrophthoe Pentandra (L) Mig Leaves with Immunostimulant Activity. Pharmacy Indonesia Magazine 8 (4): 227-231.

[6] Alexander A, Qureshi A, Kumari L, Vaishnav P, Sharma M, Saraf, S. 2014. Role of herbal bioactive as a potential bioavailability enhancer for Active Pharmaceutical Ingredients. Fitoterapia. 97, 1-14.

[7] Handayani, Hana., Sriherfyna, Feronika H., and Yunianta. 2016. Antioxidant Extraction of Soursop LeavesMethod Ultrasonic Bath (Study of Material Ratio: Solvent and Length of Extraction). Food Journal and Agroindustry. Volume 4, Number 1: 262-272.

[8] Muti'ah, R. 2004. Development of Anticancer Fitopharmaca. Malang: LP2M and UIN MALIKI PRESS.

[9] Meiyanto E, Septisetyani EP. 2005. Efek Antiproliferatif dan Apoptosis Fraksi Fenolik Ekstrak Etanolik Daun Gynura procumberns (Lour.) Merr. Terhadap Sel HeLa. Artocarpus 5:1-12.

[10] Mutiah, Roihatul (2017) Studi Efikasi dan Keamanan Ekstrak Akar dan Daun Calotropis gigantea Terhadap Sel Kanker Kolon dan Sel Kanker Payudara Secara In Vitro. Journal of Islamic Medicine, 1 (2): 67-75.

[11] Mutiah, Roihatul and Listiyana, Anik and Suryadinata, Arief (2017) Anticancer Activity of Combination of Benalu Belimbing (Macrosolen cochinensis) Extract and Sabrang Onion (Eleutherine palmifolia (L) Merr) on Cervical Cancer Hela Cell Line. Traditional Medicine Journal, 22 (3): 146-152.

[12] Mutiah, Roihatul and Listiyana, Anik and Indradmojo, Christyaji and Griana, Tias Pramesti and Dwi, Hardiyanti Helda and Atmaja, Ria Ramadhani Dwi. 2017. Induction of Apoptosis and Phase-Cell Cycle Inhibition of G0-G1, S, G2-M of T47D Breast Cancer Cells on Treatment with Ethyl Acetate Fraction of Jackfruit Parasite Leaves (Macrosolen cochinensis). Journal of Applied Pharmaceutical Science, 07 (10). pp. 138-143. ISSN 2231-3354

[13] N Verma, S Shukla. 2015. Impact of various factors responsible for fluctuation in plant Journal of Applied Research on Medicinal and Aromatic Plants; 2(4)

[14] Basmal, J., Amini, S., Sugiyono, \& Murniyati. 2009. National Seminar on Marine and Fisheries Product and Biotechnology Processing. Jakarta.

[15] Mutiah R, Sukardiman S, Widyawaruyanti A. 2018. Calotroposid A: a Glycosides Terpenoids from Calotropis gigantea Induces Apoptosis of Colon Cancer WiDr Cells through Cell Cycle Arrest G2/M and Caspase 8 Expression. Asian Pacific Journal of Cancer Prevention, 19 (6):1457-1464.

[16] Artanti, N., Firmansyah, T, Darmawan, A., 2012. Bioactivities Evaluation of Indonesian Mistletoes (Dendrophthoe pentandra (L.) Miq.) Leaves Extracts. Journal of Applied Pharmaceutical Science 02 (01); 24-27. 


\section{J. Islamic Pharm. 2019. 4(1): 1-8}

Table 1. Cytotoxic test results and toxicity of extracts of mango parasite leaves (D. pentandra) from 4 locations

\begin{tabular}{|c|l|c|c|}
\hline No. & \multicolumn{1}{|c|}{ Location } & $\mathbf{I C}_{\mathbf{5 0}}(\boldsymbol{\mu g} / \mathbf{m l}) \pm \mathbf{S D}^{*}$ & $\mathbf{L C}_{\mathbf{5 0}}(\boldsymbol{\mu g} / \mathbf{m l}) \pm \mathbf{S D}$ \\
\hline 1 & Kediri & $304.79 \pm 26.7204402$ & $26.61 \pm 16.20$ \\
\hline 2 & Pekalongan & $4646.34 \pm 423.280308$ & $1583.75 \pm 561.09$ \\
\hline 3 & Sumatra & $540.91 \pm 0.94252431$ & $4845.32 \pm 92.13$ \\
\hline 4 & Kalimantan & $287.39 \pm 20.1914535$ & $798.28 \pm 171.59$ \\
\hline
\end{tabular}

*SD: Standart Deviation with three replication of treatment

Table 2. Results of calculation of selectivity index (SI) extract from 4 locations growing

\begin{tabular}{|c|l|c|c|}
\hline No & Location growing & Index of Selectivity (SI) & Interpretation \\
\hline 1 & Kediri & 0.0087 & Less selective \\
\hline 2 & Pekalongan & 0.3409 & Less selective \\
\hline 3 & Lampung & 8.957 & Selective \\
\hline 4 & Bulungan & 2,778 & Selective \\
\hline
\end{tabular}

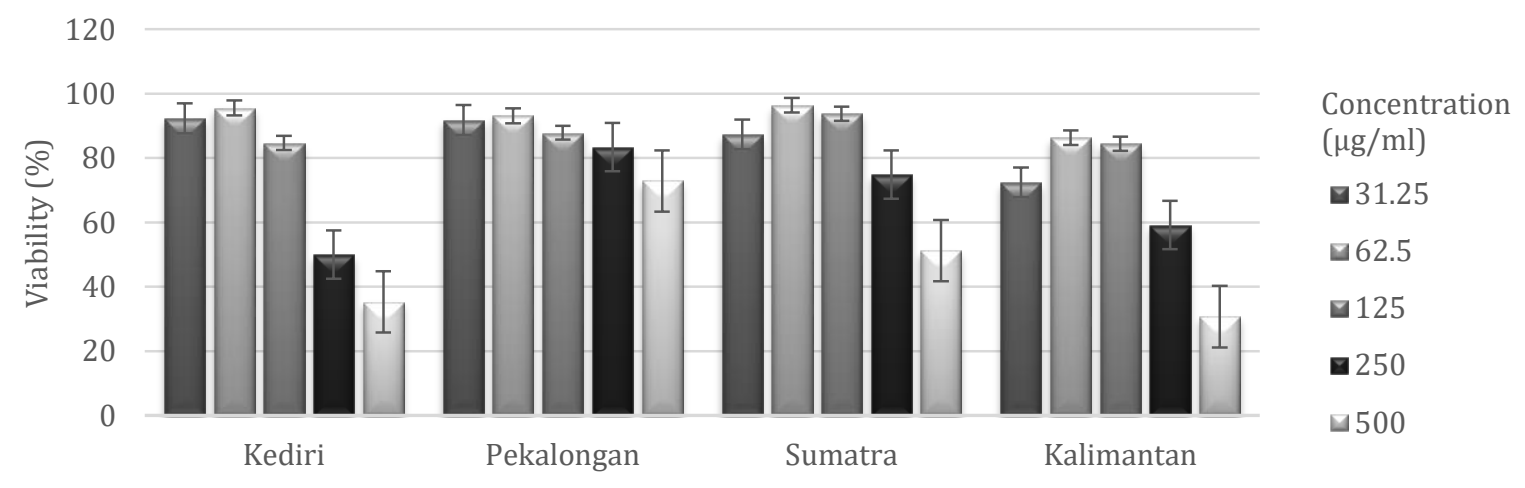

Figure 1. Graph of \% profile viability of T47D breast cancer cells at a concentration of 500; 250; $62.5 ; 31.25 \mu \mathrm{g} / \mathrm{ml}$ from the locations of Kediri, Pekalongan, Sumatra and Kalimantan

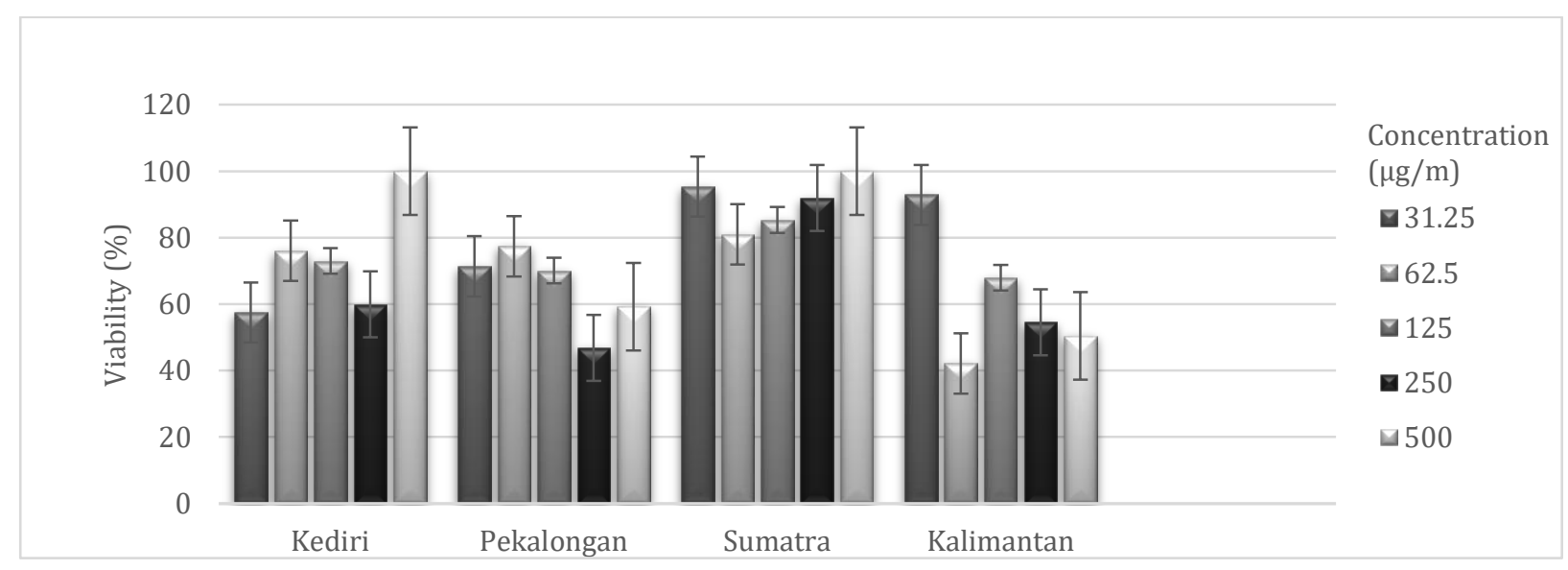

Figure 2. Graph of\% profile of viability of T47D breast cancer cells at a concentration of 500; $250 ; 62.5 ; 31.25 \mu \mathrm{g} / \mathrm{ml}$ from the locations of Kediri, Pekalongan, Sumatra and Kalimantan.

J. Islamic Pharm., an open access journal

ISSN: 2527-6123 